\title{
KNOWLEDGE-BASED MODEL OF COMPETITION IN RESTAURANT INDUSTRY: A QUALITATIVE STUDY ABOUT CULINARY COMPETENCE, CREATIVITY, AND INNOVATION IN FIVE FULL-SERVICE RESTAURANTS IN JAKARTA
}

\author{
Napitupulu Joshua H., Astuti Endang Siti, Hamid Djamhur, Rahardjo Kusdi \\ Faculty of Administrative Science, University of Brawijaya, Malang, Indonesia \\ E-mail: josnapit@yahoo.com
}

\begin{abstract}
The purpose of the study is to have an in-depth description in the form of the analysis of culinary competence, creativity and innovation that develops knowledge-based model of competence in full-service restaurant business. Studies on restaurant generally focused on customers more particularly customer's satisfaction and loyalty, and very few studies discussed internal competitive factors in restaurant business. The study aims at filling out the research gap, using knowledge-based approach that is through culinary competence, creativity and innovation. The main question is how to the restaurants develop competitive sense using thoe aspects of internal capabilities. The study is a qualitative study taking five full-service restaurants in Jakarta as case study. The data collection methods are observations and in-depth interviews with the restaurant owners, the managers or heads of restaurants, the chefs and kitchen staffs, the waiters and floor managers. The findings show that the implementation of culinary competence is carried out by the chefs designed by the restaurant owners, where the effectiveness really depends on how consistent the implementation of culinary competence is as well as how accurate the identification of customers' segmentation is. In terms of creativity, it is found out that the simultaneous implementation of creativity between sustainable, incremental, break-through, and profitable creativities will support the success of the restaurants to win the competition. As an addition, in terms of innovation, the findings reveal that the restaurants create innovations in various aspects (product, process, function, operation, coordination) in order to attract more customers. In general, the findings of the study show should a restaurant implement culinary competition creativity and innovation by developing knowledge as source of competitive sense to win the competition in restaurant business.
\end{abstract}

\section{KEY WORDS}

Knowledge-based model of competition, culinary competence, creativity, innovation, fullservice restaurant.

Restaurant business in Indonesia is growing rapidly especially in the period of 2008 and 2009 with the growth percentage $38.39 \%$ and $20.98 \%$ respectively; the total number of mid-scale and big-scale restaurants in 2011 is 2.977 restaurants (The Minsitry of Tourism and Creative Economics, 2014). Even though the growth of restaurants decline in the following years, that is $7.84 \%$ and $2.09 \%$ as the growth percentage in 2010 and 2011 , the data shows such bright future in restaurant business. The restaurant business grows more quickly in Jakarta, the capital city with the total population around 10 millions, than it is nation wide with $42.78 \%$ and $27.53 \%$ as the percentage of the growth of Jakarta's restaurant business in 2008 and 2009; the total number of restaurants in Jakarta in 2011 is 1,361 or $46.6 \%$ out of the total number of restaurants in Indonesia (The Minsitry of Tourism and Creative Economics, 2014). Therefore, the growth of restaurant business in Indonesia, especially Jakarta is an interesting research focus.

The study in particular focuses on knowledge-based model of competition that involves culinary competence, creativity and innovation. The pioneers of such model are Birdir and Pearson (2000) who develop chefs model of competence based on two types namely research-focussed model and management-focused model and Hu (2010) who later develop 
the model of competence resulting in a model of comepetence that combines both researchfocussed and management-focused model, among others.

Research Gap. There are very few studies about restaurant business in Indonesia. As an addition, scientific literature about restaurant business abroad is limited to the analysis of customer's satisfaction (see e.g., Andaleeb \& Conway, 2006; Ryu, et.al., 2012; Gupta, et.al., 2007; Koutroumanis, 2005; Sweeney et.al., 1992). The findings of the study generally focus on three main factors that influence restaurant customer's satisfaction, the quality of food, price and service. It is very rarely to find studies discussing how restaurants develop internal sense of competition.

Small number of studies that start the knowledge-bases model are studies conducted by Horng and $\mathrm{Hu}$ (2009) of which topic is the effect of creative culinary curriculum; Suskind, et.al (2007) of which topic is standard of organization and co-worker support; Leschziner (2007) of which topic is chef's career choice and Butler (2006) of which topic is restaurant organizational competence. However, there has yet been specific study that connects the internal factors as the source of competitive advantage in restaurant business.

\section{LITERATURE REVIEW}

Knowledge-based Model of Competence. Knowledge-based model of competence is the futher development of resource-based model, which is resource-based view paradigm, specifically analyze knowledge as resource. Knowledge is considered as the most detrimental feauture in knowledge-based economy that there is a quotation that says knowledge is the most important resource that can be controlled by a firm (Barney and Arikan, 2002: 139; Wiklund and Shepherd, 2003). Knowledge is the most important part if core competence as the internal factor that determine a company's sense of competitiveness. Besides that, knowledge is the source to incerase company's intellectual capital (Leonard-Barton, 1992). Knowledge-based competition is a model using particular premises, namely (1) a company is seen as an institution that integrates knowledge; (2) knowledge relies within an individual in the form of specialized knowledge; (3) the most important role of organization is to apply knowledge, instead of to create one (Grant, 1996).

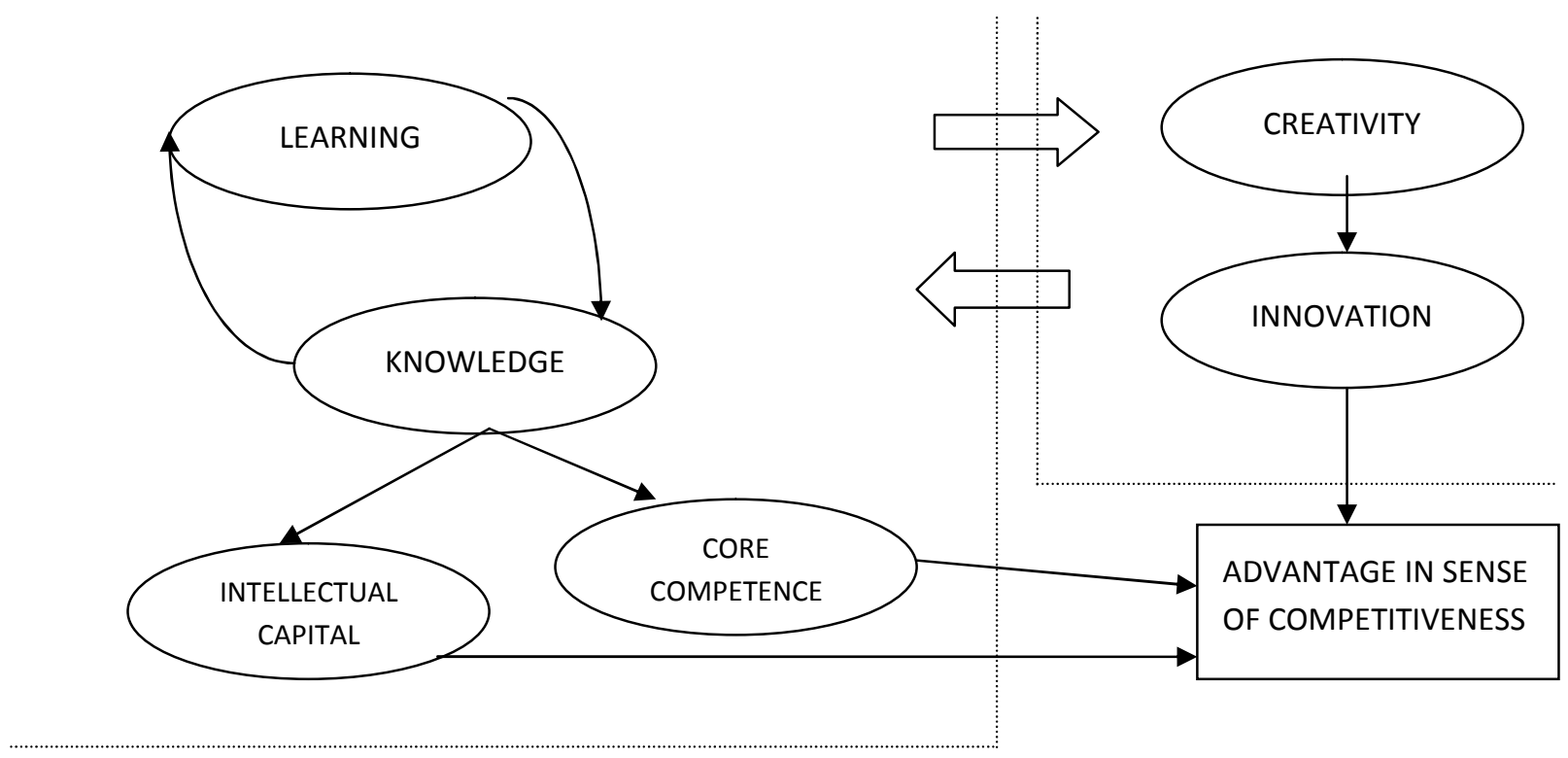

Figure 1 - Knowledge-based Model of Competence. Source: Various sources, combined by the authors

Knowledge and learning are of necessities in order to encourage the the development of creativity and innovation; similar to Tidd et.al. (2006) who state that knowledge is the basis of the 21 st century competition; as the consequences, organizational learning is basically 
considered as an opportunity to increase sense of competence. The knowledge-based model of competence used in the study, as described in Picture 1, consists of two major streams, namely (1) learning and knowledge that results in core competition and intellectual capital, and (2) creativity and innovation as sources for the creation of new products or service which gives additional customer value. Through knowledge creation, process of organizational learning is considered effective to fulfill developmental need of core competency in an organization (Long and Vickers-Koch, 1995). Even Garvin et al. (2008) believes that every company should make itself learning organization because knowledge-sharing activities lead to creativity and innovation very important to win competition, where such activities mainly appear as the output of communication taking place among people in an organization, which at certain point triggers creativity to generate better ideas.

Culinary competence used in the study is derived from Birdir and Pearson's (2000) idea that distinguish two types of chef, research-focused and management-focused. The idea is developed by $\mathrm{Hu}$ (2010: 66) using a qualitative study involving 20 experts in hospitality industry and people working in the field from various countries. Hu (2010) reveals seven dimensions of culinary competence namely culture (9 items), aesthetic ( 9 items), products (11 items), management (13 items), creativity (10 items), service (8 items), technology (9 items), with the total of 69 items of competence.

The element of creativity is considered to play such important role in the 21st century competition because creativity and knowledge are tightly connected to each other and inseparable (Amabile, 1997; Lampel et.al, 2000; Leonard and Sensiper, 1998). Creativity in turn allows the birth of innovations which become the source of advantage in sense of competitiveness for a company including one in restaurant business. The aspect of creativity in the study is studied through DeGraf and Lawrence's (2002) idea that develops profile concept and creativity type, where each refers to both individual characteristics and different organizations. There are four creativity profiles being developed namely incubate, imagine, improve and invest. These terms refer to the types of creativity stand out from each profile; incubate tends to use sustainable creativity; improve uses incremental creativity, imagine uses breakthrough creativity and finally invest uses profitable creativity. Futhermore, innovation is classified based on its type, product, process, function, operation and coordination.

\section{RESEARCH METHODOLOGY}

Research Design. The study is a qualitative one with case study approach taking five full-service restaurants in Jakarta as the settings due to their business characteristics variation. Eisenhardt (1998) defines case study as «a research strategy which focuses on understanding the dynamics present with single settings." Single setting used in the study is the competition in restaurant business as background so that the analysis of culinary competence, creativity and innovation is considered as response to the competition itself, as translated by the restaurants selected as the setting of the study.

Sampling. The study employs purposive sampling, more specifically stratified intensity sampling (Patton, 2002). The sampling method is called stratified sample because it takes representative from each stratum in the organization of retaurant business being the focus of the study. Futhermore, it is considered intensity sampling because the selection is carried out based on the evaluation towards high intensity of capabilities but not too extreme. Overall, there are 35 informants consist of 5 managers/ head of restaurants, 15 chefs, cooks and other kitchen staffs, 10 operational managers, waiters and other floor staffs as well as 5 supporting staffs (cashiers, administration staffs and others). Besides that, additional information is obtained from some of the restaurant owners the researchers get the chance to interview. 


\section{FINDINGS AND DISCUSSION}

The Profile of the Restaurants. The five full-service restaurants being observed havedifferent business profiles as seen in Table 1. Two restaurants, Ecletic Restaurant and TRS Dinner, are located in "Cilandak Town Square» or "Citos,» a shopping mall in South Jakarta well-known as the only shopping mall with culinary concept. Restaurant Nannini and Madame Lily are located in Plaza Indonesia, the most prestigious shopping mall in Jakarta. Finally, Beranda Kitchen Restaurant is located out of the shopping malls.

Table 1 - The Profile of the Restaurants

\begin{tabular}{|c|c|c|c|c|c|}
\hline No. & $\begin{array}{c}\text { Restaurant } \\
\text { Name }\end{array}$ & Type & Capacity & Structure of Organization & Culinary Concept \\
\hline 1. & $\begin{array}{l}\text { Beranda } \\
\text { Kitchen \& } \\
\text { Lounge }\end{array}$ & $\begin{array}{c}\text { Family } \\
\text { Restaurant }\end{array}$ & $\begin{array}{l}90 \text { chairs ( } 34 \text { chairs } \\
\text { on the top floor, } 56 \\
\text { on the bottom floor) }\end{array}$ & $\begin{array}{c}\text { Functional structure (bar, } \\
\text { kitchen, floor and } \\
\text { marketing) }\end{array}$ & $\begin{array}{l}\text { Melayu Medan } \\
\text { cooking }\end{array}$ \\
\hline 2. & $\begin{array}{l}\text { Nannini Italian } \\
\text { Steak \& Grill }\end{array}$ & $\begin{array}{c}\text { Casual } \\
\text { Restaurant }\end{array}$ & 76 chairs & $\begin{array}{c}\text { Functional structure (floor, } \\
\text { bar, kitchen) }\end{array}$ & $\begin{array}{c}\text { Innovative menu } \\
\text { creation }\end{array}$ \\
\hline 3. & $\begin{array}{l}\text { Ecletic Resto } \\
\qquad \text { Bar }\end{array}$ & $\begin{array}{c}\text { Casual } \\
\text { Restaurant }\end{array}$ & 215 chairs & $\begin{array}{l}\text { Functional structure } \\
\text { (finance, marketing, } \\
\text { entertainment, and } \\
\text { kitchen chef) }\end{array}$ & $\begin{array}{l}\text { East Java cooking; } \\
\text { restaurant-bar } \\
\text { concept }\end{array}$ \\
\hline 4. & TRS Dinner & $\begin{array}{c}\text { Casual } \\
\text { Restaurant, } \\
\text { American home } \\
\text { cooking }\end{array}$ & $\begin{array}{l}130 \text { chairs ( } 30 \\
\text { chairs outdoor, } 100 \\
\text { chairs indoor) }\end{array}$ & $\begin{array}{l}\text { Functional structure (floor } \\
\text { and kitchen) }\end{array}$ & $\begin{array}{l}\text { Simple American- } \\
\text { style cooking }\end{array}$ \\
\hline 5. & $\begin{array}{l}\text { Madame Lily } \\
\text { Cafe }\end{array}$ & Fine dinning & 120 chairs & $\begin{array}{l}\text { Functional structure } \\
\text { (operational, kitchen, } \\
\text { administration) }\end{array}$ & $\begin{array}{l}\text { Fusion cooking } \\
\text { (traditional vs } \\
\text { international) }\end{array}$ \\
\hline
\end{tabular}

Each of the restaurants has different structure of organization, but in general all of them use the functional structure especially to divide the main function (kitchen and floor) and additional function (bar, entertainment, purchasing, marketing, administration and others). The business strategy they choose is different as well. Beranda Restaurant is specializing in (differentiation strategy) in "Melayu Medan» food which is rarely found in Jakarta. Nannini Restaurant emphasizes on the creation of creative and innovative menu, while Ecletic Restaurant combines restaurant and bar concepts. TRS Restaurant offers simplicity of American Home Cooking style of food. At last, Madame Lily depends upon fusion cooking technique with the combination of Indonesian and international culinary traditions.

Culinary Competence. The result of the questionnaire and interviews with the chefs of the five full-service restaurants show that each of the restaurants develops different culinary competence. The analysis show that the model of competence is applied in a different way in each of the restaurants. Five case studies discussed above have generally shown wide variation on how a model of competence is established and developed in the context of Indonesian full-service restaurants, particularly in Jakarta. It also illustrates how fierce the competition among the restaurants is, and as the consequences, restaurant owners and/or managers keep on making new creation which is based on particular model of competence being used as the basis in developing the characteristics of a restaurants.

Based on the chefs, Madame Lily has the highest total in culinary competence (343) followed by Ecletic (311), Beranda Restaurant (307) and TRS Restaurant (275); Nannini Restaurant has the lowes score that is 263 . The findings show that the percentage of items in Hu's culinary competence is not linear, It means the higher percentage does not always give higher, more positive effect towards restaurant's performance and competitive sense. More important thing is the application of each of the types of culinary competence, where a lot of factors plays their roles. As mentioned by Ford and Ettienne (2003), the characteristic of restaurant service is a complex service consists of guess-related variables (background, demographic, behavior), service provider variables (demographic, behavior, mood and emotion) and contextual variables (organizational environment, structure, leadership, and coworker relationship). 
Table 2 - Model of Culinary Competence Category

\begin{tabular}{|c|c|c|c|}
\hline Restaurant & $\begin{array}{l}\text { Type of Culinary } \\
\text { Competence }\end{array}$ & $\begin{array}{c}\text { Dimension of Weak } \\
\text { Competence }\end{array}$ & Reason \\
\hline Beranda & Combination & $\begin{array}{l}\text { Technology (4.22), } \\
\text { Culture (4.33) }\end{array}$ & $\begin{array}{l}\text { - The menus do not require sophisticated } \\
\text { application of technology } \\
\text { - The culinary culture solely focuses on Melayu } \\
\text { cooking }\end{array}$ \\
\hline Nannini & $\begin{array}{l}\text { Research- } \\
\text { focussed }\end{array}$ & $\begin{array}{l}\text { Service }(3.00), \\
\text { Management }(3.23) \text {, } \\
\text { Product }(3.64)\end{array}$ & $\begin{array}{l}\text { The chef focuses on research and development } \\
\text { of the products, while service, management and } \\
\text { product become the responsibility of outlet } \\
\text { kitchen }\end{array}$ \\
\hline Ecletic & $\begin{array}{l}\text { Management- } \\
\text { focussed }\end{array}$ & $\begin{array}{l}\text { Service }(4.13), \\
\text { Technology (3.66), } \\
\text { Product }(4.36)\end{array}$ & $\begin{array}{l}\text { - The service competence declines because the } \\
\text { chef has an additional role in entertainment } \\
\text { division } \\
\text { - Sophisticated technology is not required to make } \\
\text { original taste of East Javanesse menus } \\
\text { - The product competence does not stand out } \\
\text { because the culinary concept keeps on changing } \\
\text { so that it disturbs the chef's focus in R\&D }\end{array}$ \\
\hline TRS & Combination & $\begin{array}{l}\text { Management }(3.62) \\
\text { Technology }(3.66) \\
\text { Product }(4.09)\end{array}$ & $\begin{array}{l}\text { - The role of the owner is pretty dominant; the chef } \\
\text { does not have much involvement in the } \\
\text { management } \\
\text { - The technology and equipmets for open kitchen } \\
\text { have been prepared; the chef can directly use } \\
\text { them } \\
\text { - The product development is simplified due to the } \\
\text { simple cooking concept }\end{array}$ \\
\hline $\begin{array}{l}\text { Madame } \\
\text { Lily }\end{array}$ & $\begin{array}{l}\text { Closer to Hu's } \\
\text { (2010) model }\end{array}$ & None & $\begin{array}{l}\text { - There is high innovation to combine Indonesian } \\
\text { food with other culinary traditions through fusion } \\
\text { cooking; chef should have broad knowledge and } \\
\text { is well-competent }\end{array}$ \\
\hline
\end{tabular}

Source: Findings of the Study.

The capability of one type of culinary competence to support restaurant performance is also determined by the combination of the factors or variables. The success of a restaurant in applying culinary competence is heavily determined by the consistent implementation of the chosen concept as the guideline to develop the dimension of competition a chef should have.

Creativity and Innovation. Table 3 shows how creativity is applied in the five full-service restaurants. Based on the table, we can see that each type of creativity is applied to different sectors as well as different actors to carry it out.

Table 3 - Implementation of Creativity in the Full-Service Restaurants

\begin{tabular}{|c|c|c|}
\hline Type of Creativity & Implementation & Actors \\
\hline $\begin{array}{l}\text { Sustainable } \\
\text { Creativity }\end{array}$ & 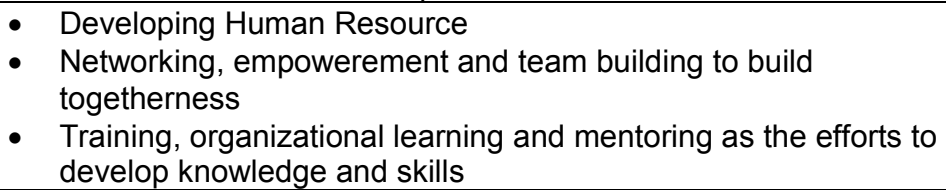 & $\begin{array}{l}\text { - Managers } \\
\text { - Supervisors }\end{array}$ \\
\hline $\begin{array}{l}\text { Incremental } \\
\text { Creativity }\end{array}$ & $\begin{array}{l}\text { - Physical design and restaurant concepts } \\
\text { - Menu development }\end{array}$ & $\begin{array}{l}\text { - Conceptors } \\
\text { - Chefs } \\
\text { - Owners/ } \\
\text { managers }\end{array}$ \\
\hline $\begin{array}{l}\text { Breakthrough } \\
\text { Creativity }\end{array}$ & - Creation of new products (fusion cooking technique) & $\begin{array}{l}\text { - Chefs } \\
\text { - Owners/ } \\
\text { managers }\end{array}$ \\
\hline Profitable Creativity & $\begin{array}{l}\text { - Increasing profit and potential for business (owner and/or } \\
\text { management) }\end{array}$ & $\begin{array}{l}\text { - Owner } \\
\text { - Managers }\end{array}$ \\
\hline
\end{tabular}

Source: Findings of the Study. 
Table 4 describes the type of innovations carried out by the five full-service restaurants being observed; from the table, we can see that each restaurant emphasizes on different types of innovation to develop their competitive advantages.

The identification towards the types of innovations carried out by the restaurants is presented in Table 5. Product as well as process innovations are the most commonly type of innovations carried out by full-service restaurants; all five of the observed restaurants carried out these types of innovations. Operational innovation is the third type of innovation most of the observed restaurants carried out; three out of the five observed restaurants carried out the innovation. Process and coordination innovations are carried out by one restaurant only, TRS Restaurant; CK bought a Japanese restaurant franchise, Little Takigawa, in order to learn the most current technology use in restaurant business. Therefore, the approach it applies to have wider coverage is better than that of the other restaurants.

Table 4 - Types of Innovations in Full-Service Restaurant

\begin{tabular}{|c|c|c|}
\hline Restaurants & Innovations & Type of Innovations \\
\hline Beranda & $\begin{array}{l}\text { - } \begin{array}{l}\text { Changing concept from ordinary restaurant into a full-service } \\
\text { restaurant }\end{array} \\
\text { Dutch mixed rice, the combination of «nasi tumpeng» and } \\
\text { Melayu style cooking } \\
\text { - } \quad \text { Exapanding the function of kitchen division to serve certain } \\
\text { events (e.g. catering service) } \\
\text { - } \begin{array}{l}\text { Providing room for big-scale events (wedding, screening) as } \\
\text { well as small-scale events (gathering, meeting, birthday, etc) }\end{array}\end{array}$ & $\begin{array}{ll}- & \text { Product } \\
\text { - } & \text { Product } \\
\text { - } & \text { Product } \\
\text { - } & \text { Operational }\end{array}$ \\
\hline Nannini & $\begin{array}{ll}\text { - } & \text { Aggresive creation of new menus } \\
\text { - } & \text { Green healthy bar for healthy lifestyle } \\
\text { - } & \text { Central kitchen for the invention of new menus } \\
\text { - } & \text { Social media utilization for promotion }\end{array}$ & $\begin{array}{ll}- & \text { Product } \\
\text { - } & \text { Product } \\
\text { - } & \text { Product } \\
\text { - } & \text { Function } \\
\end{array}$ \\
\hline Eecletic & 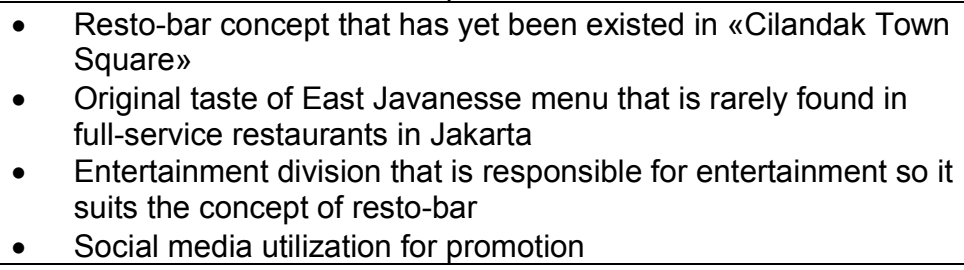 & $\begin{array}{ll}\text { - } & \text { Product } \\
\text { - } & \text { Product } \\
\text { - } & \text { Function } \\
\text { - } & \text { Operational }\end{array}$ \\
\hline TRS & 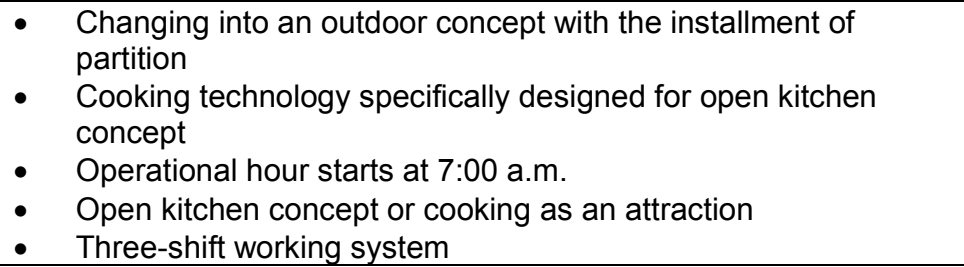 & $\begin{array}{ll}- & \text { Product } \\
\text { - } & \text { Process } \\
\text { - } & \text { Process } \\
\text { - } & \text { Function } \\
\text { - } & \text { Coordination }\end{array}$ \\
\hline $\begin{array}{l}\text { Madame } \\
\text { Lily }\end{array}$ & $\begin{array}{l}\text { - } \quad \text { New products with fusion cooking concept } \\
\text { - } \quad \text { A clasic-minimalistic-traditional customized interior design } \\
\text { - } \quad \text { Hospitality advisor as a consultant with special position } \\
\text { - } \quad \text { Social media utilization for promotion } \\
\text { - } \quad \text { Developing outlets (there are currently } 3 \text { outlets and the short- } \\
\quad \text { term target is to have } 10 \text { outlets all over Indonesia }\end{array}$ & $\begin{array}{ll}\text { - } & \text { Product } \\
\text { - } & \text { Product } \\
\text { - } & \text { Function } \\
\text { - } & \text { Operational } \\
\text { - } & \text { Operational }\end{array}$ \\
\hline
\end{tabular}

Source: Findings of the Study.

Table 5 - The Implementation of the Full-Service Restaurants Innovations

\begin{tabular}{|c|c|c|c|c|c|}
\hline \multirow{2}{*}{ Restaurant } & \multicolumn{5}{|c|}{ Type of Innovations } \\
\cline { 2 - 6 } & Product & Process & Function & Operational & Coordination \\
\hline Beranda & $\mathrm{X}$ & - & $\mathrm{X}$ & $\mathrm{X}$ & - \\
\hline Nannini & $\mathrm{X}$ & - & $\mathrm{X}$ & $\mathrm{X}$ & - \\
\hline Ecletic & $\mathrm{X}$ & - & $\mathrm{X}$ & $\mathrm{X}$ & - \\
\hline TRS & $\mathrm{X}$ & $\mathrm{X}$ & $\mathrm{X}$ & - & $\mathrm{X}$ \\
\hline Madame Lily & $\mathrm{X}$ & - & $\mathrm{X}$ & - & - \\
\hline
\end{tabular}

Source: Findings of the Study. 
Radu (2007) explains that innovations in hospitality industry sector has their own distinctive features and are more sophisticated than innovations in the manufacturing or other inductrial sectors. The characteristics of the innovations in hospital industry are (1) emphaisizing on continuous, constant creation of new service in the form of radical change or the modification of the existing service; (2) strictly limited knowledge about how to build a successful innovation as well as the new development of particular service; as the effect, many times the managers have to rely on their intuitionsor feelings, speculations, and experiences about some key factors that influence the success of innovations; (3) the characteristics of the innovations is mostly intangible so it is hard to monitor and evaluate; success or failure are not the result of the management of one or two activities only, instead they become the result of a number of well-managed and well-balanced aspects. The success of TRS Restaurant to develop wider innovations compared to the other full-service restaurants shows that intuition or feeling, speculation, and experience have instrumental roles in hospitality industry innovations including restaurants.

Knowledge-based Model of Competence. Table 6 shows restaurant sense of competitiveness can be seen from the knowledge they have and each of the restaurants has its own ways to design the internal sense of competitiveness. Beranda Restaurant has relatively low level of learning because there has not been special efforts to increase the competence of the staffs except the guidance and mentoring done by the senior waitresses to the new waitresses. The chef's core competence is relatively low because the chefs graduated from public senior high schools and they only autodidact culinary skills. The chefs had never attended formal trainings or trainings to increase their knowledge in the culinary sector. Thus, it can be infered that there has yet been such intensive development of intellectual capital and knowledge has yet been considered as an advantage in culnary competition. As a conclusion, the implementation of the knowledge-based model of competition has yet been applied well in Beranda Restaurant.

Table 6 - Knowledge as Intellectual Capital in Full-Service Restaurants

\begin{tabular}{|c|c|c|c|c|}
\hline Restaurant & Learning & $\begin{array}{c}\text { Knowledge } \\
\text { Sharing }\end{array}$ & Chef Core Competence & $\begin{array}{c}\text { Intellectual } \\
\text { Capital } \\
\text { Development }\end{array}$ \\
\hline Beranda & Low & Low & Senor high school diploma, autodidact culinary & Low \\
\hline learning & High \\
\hline Ecletic & Low & Low & $\begin{array}{c}\text { Engineering senior high school diploma, } \\
\text { autodidact culinary learning }\end{array}$ & Low \\
\hline TRS & Average & Average & $\begin{array}{c}\text { Senor high school diploma, autodidact culinary } \\
\text { learning }\end{array}$ & Average \\
\hline $\begin{array}{c}\text { Madame } \\
\text { Lily }\end{array}$ & High & Low & $\begin{array}{c}\text { Graduate from a three-year program of the Swiss } \\
\text { Management Hotel School («STP Bandung»), } \\
\text { international work experience (the USA and } \\
\text { Switzerland) }\end{array}$ & Average \\
\hline
\end{tabular}

Source: Findings of the Study.

Nannini Restaurant has high level of learning where the art of culinary is considered as an experimental arena and huge learning opportunity. Continuous research is conducted in the central kitchen involving the central kitchen and outlet kitchen chefs, where cooks and other staffs taste and give their opinions toward tester, a testing product that should be evaluated before being served to the customers. The knowledge-sharing activity is high especially one related to the culinary as both products and traditions. The chefs' core competence is relatively high because the chefs not only have senior high school diplomas, but also attended a number of food and culinary courses in the USA as well as international working experiences. The development of intellectual capital occurs continuously and intensively so that the restaurant succeeds in the development of knowledge mastery and new culinary skills. In conclusion, the knowledge-based model of competition is implemented well in Nannini Restaurant. 
Ecletic Restaurant has low level of learning where there has yet been any specific efforts to increase the competence of the staffs. The individual learning only occurs at the lowest level in the form of on-job training to the new waitress or the staff kitchen learning process to increase their culinary skills which occurs during the break. The collective learning activities have either rarely or never been conducted. The knowledge-sharing components seem to be low because there is no time allocated for discussion or brainstorming to share some thoughts about some problems encountered by the restaurant. The chefs' core competence is relatively low because the chefs have engineering senior high school diplomas and prvious working experiences in other restaurants. Neither the restaurant owner nor the manager pays any special attention on the development of intellectual capacity. In short, the knowledge-based model of competition has yet been implemented well in Ecletic Restaurant.

TRS Restaurant is different from the other four restaurants because CK as the owner has wide knowledge, skills and experiences in the culinary sector. There is both direct and indirect transfer of knowledge towards the staffs in a number of activities involving the owners. The learning process is not conducted systematically or in an organized manner; instead it is in the form of discussions and sharing during the beginning process of strategic formulation, concept and physical design of the restaurant. Therefore, the learning process is at the average level. Similarly, the knowledge sharing especially from CK to the staffs is not conducted systematically or in an organized manner either; instead it is considered as a part of the staffs' duties and work. The chef core competence is not the best because they only have senior high school diplomas and autodidact culinary lesson. The chefs have never attended any courses or formal trainings to increase their knowledge and skills in culinary. Therefore, the development of intellectual capital in the restaurant is average. As a conclusion, the knowledge-based model of competition in TRS Restaurant has been implemented pretty well, however it can still be improved.

Madame Lily Restaurant has high learning component especially in the decisionmaking level involving the restaurant owners, consultants, and chefs. The process of concept design and preparation occurs intensively so that it becomes such effective learning process to develop the restaurant's resource in the form of knowledge. However, the knowledgesharing activity does not involve the staffs so it can be concluded that the activity is at the low level. The core competence of the chefs is relatively good because they graduated from a three-year program of the Swiss Management Hotel School («STP Bandung») and had international work experience in the USA and Switzerland. The development of intellectual capacity in the restaurant occurs in a lateral manner where the knowledge, skills and experience obtained in the process of running the restaurant are considered as the capital or resource to conceptualize the new outlets the restaurant plans to have. In conclusion, the knowledge-based model of competition in Madame Lily Restaurant has been implemented pretty well, yet it has yet achieved the optimum level.

The analysis towards the implementation of knowledge as resource in the five fullservice restaurant shows that in general the full-service restaurants have yet implemented the knowledge-based model of competence. There is only one restaurant that specifically pays huge attention in the development of knowledge-based model of competence through learning, knowledge-sharing and the development of chef core comepetence; the name of the restaurant is Nannini Restaurant.

\section{CONCLUSION}

The findings of the study shows culinary competence is a pivotal factor in developing knowledge-based advantage in restaurant industry. The findings also show that culinary competence is not a static model; instead it is a group of specific competence and should be renewed overtime to anticipate business competition. The findings are in line with Naismith (2006) about the principles of the development of model of competence.

In terms of creativity, the findings of the study is in line with DeGraf and Lawrence (2002) that creativty in an organization is generally the combination of the four types of 
creativity; the success of an organization in the application of creativity depends on how suitable and accurate the development of the creativity profile is to each group/ division or at the individual level. Restaurant business is a hospitality business where various aspects work simultaneously as a whole to develop restaurant service; all aspects have their own element of creativity for example the quality of food, physical decoration, as well as service as a unity (Sulek and Hensley, 2004).

In terms of innovation, the findings of the study is in line with the opinion which states that restaurant business should keep making innovations due to the following factors namely change and customers' characteristic development (Costa et al., 2001, 2007; Hu, 2010), the pressure of high competition (Melia, 2011) as well as the demand of service quality and value of money of products or service offered (Jones, 2009). Furthermore, the findings of the study show that full-service restaurant should combine innovations in all of their aspects (product, process, function, operation and coordination) in order to achieve the most optimum result in customer satisfaction.

Finally, related to knowledge-based model of competence, the study reveals an important finding that not all full-service restaurants are able to develop knowledge as resorce, be it in the form of the development of chef core competence or through learning process. There are some factors to why the restaurants are unable to develop knowledge as resource so that in turns they are unable to create business creation and innovation. The low chef competence as well as lack of restaurant owners' attention toward learning process are the causes why some full-service restaurants cannot develop knowledge-based model of competence well.

\section{REFERENCES}

1. Amabile, T.M. (1997) «Motivating creativity in organizations: On doing what you love and loving what you do», California Management Review, Vol. 40 (1), pp. 39-58.

2. Andaleeb, S. S. and Conway, C. (2006) «Customer satisfaction in the restaurant industry: an examination of the transaction-specific model», Journal of Services Marketing Vol. 20 (1), pp. 3-11.

3. Barney J.B. and Arikan A.M. (2002) «The resource-based view: origins and implications». Dalam The Blackwell Handbook of Strategic Management, Hitt MA, Freeman RE, Harrison JS (eds). Blackwell: Oxford, UK; 124-188.

4. Birdir, K., and Pearson, T. E. (2000). Research chefs' competencies: A Delphi approach. International Journal of Contemporary Hospitality Management, 12, page 205-209.

5. Butler, B.D. (2006) «A pilot study of essential competencies as perceived by multi-unit operations and human resources leaders in the restaurant industry», tesis pada Faculty of the Graduate College of the Oklahoma State University, USA.

6. Costa, A.I.A, Dekker, M., Beumer, R.R., Rombouts, F.M. and Jongen, W.M.F. (2001) «A consumer-oriented classification system for home meal replacements», Food Quality and Preference, 12, page 229-242.

7. Costa, A.I.A., Schoolmeester, D., Dekker, M. and Jongen, W.M.F. (2007) «To cook or not to cook: a means-end study of the motivations behind meal choice», Food Quality and Preference, 18, page 77-88.

8. DeGraf, J. and Lawrence, K.A (2002) Creativity at Work: Developing the Right Practices to Make Innovation Happen, Michigan: John Wiley \& Sons, Inc.

9. Eisenhardt, K.M (1989), "Building theories from case study research", Academy of Management Review, Vol. 14(4), page 532-550.

10. Ford, W.S.Z., and Etienne, C.N. (2003) «Can I Help You? A Framework for interdisciplinary research on customer-service encounters», Management Communication Quarterly, Vol. (7), pp. 413-441.

11. Garvin, D.A., Edmondson, A.C. and Gino, F. (2008) «ls yours a learning organization?» Harvard Business Review, March, page 109-116.

12. Grant, R. (1996) 'Towards a knowledge-based view of the firm', Strategic Management Journal, Vol. 17, pp.109-122. 
13. Gupta, S., McLaughli, E., and Gomez, M. (2007), "Guest Satisfaction and Restaurant Performance», Cornell Hotel and Restaurant Administration Quarterly; Vol. 48 (3), pp. 284-298.

14. Horng, J.S. and Hu, M.L, (2009) «The impact of creative culinary curriculum on creative culinary process and performance», Journal of Hospitality, Leisure, Sport and Tourism Education, Vol. 8 (2), hal. 34-46.

15. Hu, M. L. (2010) «Discovering culinary competency: An innovative approach», Journal of Hospitality, Leisure, Sport and Tourism Education, Vol. 9(1), page 65-72.

16. Kementerian Pariwisata dan Ekonomi Kreatif, 2014. accessed from (http://kemenpar.go.id/userfiles/file/E_1\%20Perkembangan\%20Usaha\%20Restoran\%20\%20RM\%20Besar\%20dan\%20Menengah\%202008\%20-\%202012.pdf)

17. Koutroumanis, D. A. (2005) Behavioral intentions in the full service restaurant industry: the effect service quality and organizational culture has on customers' intentions to return, disertasi pada $\mathrm{H}$. Wayne Huizenga School of Business and Entrepreneurshi, Nova Southeastern University, USA.

18. Lampel, J., Lant, T., and Shamsie, J. (2000) "Balancing Act: Learning from Organizing Practices in Cultural Industries." Organization Science Vol. 11, page 263-269

19. Leonard, D., \& Sensiper, S. (1998) "The role of tacit knowledge in group innovation», California Management Review, Vol. 40, page 112-132.

20. Leonard-Barton D. (1992) «Core capabilities and core rigidities: a paradox in managing new product development» Strategic Management Journal, Summer Special Issue 13: 111-125.

21. Leschziner, V. (2007), Recipes for success culinary styles, professional careers, and institutional patterns in the field of high cuisine, disertasi pada Graduate School-New Brunswick Rutgers, The State University of New Jersey.

22. Long, C. and Vickers-Koch, M. (1995) «Using Core Capabilities to Create Competitive Advantage», Organizational Dynamics, Vol. 24, page 6-22.

23. Melia, D.M (2011) "Trends in the food and beverage sector of the hospitality industry», paper untuk EuroCHRIE Conference, Dubrovnik, Croatia, October 2011.

24. Naismith, L. (2006): Literature Review. In Mobile Technologies and Learning. Futurelab, Birmingham. Routes into Languages http://www.routesintolanguages.ac.u

25. Patton, M. Q. (2002). Qualitative research \& evaluation methods (3rd ed.). Thousand Oaks, CA: Sage.

26. Radu, E. (2007) «Inovation in the Hospitality Industry» http://steconomiceuoradea.ro/anale/volume/2007/1/053.pdf

27. Ryu, K., Lee, H., and Kim, W.G. (2012) «The influence of the quality of the physical environment, food, and service on restaurant image, customer perceived value, customer satisfaction, and behavioral intentions», International Journal of Contemporary Hospitality Management, Vol. 24 (2), page 200-223.

28. Sulek, J.M., and Hasley, R.L. (2004), «The relative importance of food, atmosphere, and fairness of wait: The case of a full-service restaurant», Cornell Hotel and Restaurant Administration Quarterly; Vol. 45 (3), page 235-247.

29. Susskind, A.M., Kacmar, M.K., and Borchgrevink, C.P (2007) «How Organizational Standards and Coworker Support Improve Restaurant Service», Cornell Hotel and Restaurant Administration Quarterly; Vol 48 (4), page 370-379.

30. Sweeney, J.C., Johnson, L.W. and Armstrong, R.W (1992), "The effect of cues on service quality expectations and service selection in a restaurant setting», The Journal of Services Marketing; Vol 6 (4), page 15-22.

31. Tidd, J., Bessant, J., \& Pavitt, K. (2006). Managing innovation: Integrating technological, market and organizational change. Third edition, Chichester, UK: Wiley \& Sons Ltd.

32. Wiklund J. and Shepherd D. (2003) «Knowledge-based resources, entrepreneurial orientation, and the performance of small and medium-sized businesses», Strategic Management Journal Vol. 24(13), page 1307-1314. 